\title{
Rasa litanga - a new genus and species of Carpenter Moth (Lepidoptera: Cossidae: Cossinae) from Sichuan Province (China)
}

\author{
Rasa litanga - новый род и виА древоточщев (Lepidoptera: \\ Cossidae: Cossinae) из провинции Сычуань (Китай)
}

\author{
A. Saldaitis ${ }^{1}$, R.V. Yakovlev ${ }^{2,3}$ \\ A. Салдаитис ${ }^{1}$, P.В. Яковлев ${ }^{2,3}$
}

\footnotetext{
${ }^{1}$ Nature Research Centre, Akademijos 2, LT-08412 Vilnius, Lithuania. E-mail: saldrasa@gmail.com

2 Altai State University, Lenina pr. 61, RF-656049 Barnaul, Russia.

${ }^{3}$ Tomsk State University, Laboratory of Biodiversity and Ecology, Lenina pr. 36, 634050 Tomsk, Russia. E-mail: yakovlev_asu@mail.ru

2 Алтайский государственный университет, пр. Ленина 61, Барнаул, 656049, Россия.

${ }^{3}$ Томский государственный университет, Лаборатория биоразнообразия и экологии, пр. Ленина 33, Томск 634050, Россия.
}

KEY WORDS: Cossidae, taxonomy, systematics, fauna, new taxa.

КЛЮЧЕВЫЕ СЛОВА: Cossidae, таксономия, систематика, фауна, новый таксон.

ABSTRACT. The article gives a description of a new genus and species, Rasa litanga, gen. et sp.n. from highlands of Sichuan (China). The description is given on two female. The images of the adult and genitalia are provided. The taxonomic position of the genus in the subfamily Cossinae has not been exactly defined.

РЕЗЮМЕ. По двум самкам описан новый род и вид Rasa litanga gen. et sp.n. из высокогорий провинции Сычуань (Китай). Даны изображения имаго, гениталий. Систематическое положение рода внутри подсемейства Cossinae четко не определено.

\section{Introduction}

Cossidae of China are quite well studied. All the known data were generalized in the monograph by our colleagues from China [Hua et al., 1990]. Later, we published some supplementary materials: new faunistic data, descriptions of new species, establishing new synonyms [Yakovlev, 2004a, b, 2011; Saldaitis \& Ivinskis, 2010; Ivinskis et al., 2012; Yakovlev et al., 2013, 2016]. Examining the highlands of Sichuan province, we collected a female of a species new to science, which was impossible to be attributed to the already described genera.

\section{Material and methods}

The genitalia were mounted in Euparal on slides following Lafontaine [2004]. The photographs of collection specimens were taken by the digital camera of Apple
iPhone 7 32GB, illuminated in Lightbox. The genital preparation was made using standard methods, is deposited in a microcapsule on a pin under the holotype. The images were processed using CorelDraw software. The single female was collected at ultraviolet light.

\section{Results}

Rasa Saldaitis et Yakovlev, gen.n.

Type species Rasa litanga Saldaitis et Yakovlev, sp.n.

DESCRIPTION. Female. Size medium. Antenna bipectinate, length of crest processes (in middle third of antenna) 1,2 times bigger than rod diameter. Length of antenna equal to 0.5 of fore wing length. Tegula and patagium pale brown. Abdomen covered with orange hairs. Fore wing pale brown, with poorly expressed dark brown pattern of transverse strokes and blurred patches and spots. Hind wing pale brown without pattern.

Female genitalia: ovipositor long, papilla analis semicircular, smooth; posterior apophyses thing, 2 times longer than anterior apophyses; posterior apophyses basally thick, apically narrowing; ostium poorly immersed, cup-like, of small diameter; antrum short, thick; ductus short; bursa bag-like, of medium size, without signa, ductus seminalis flows into place of antrum transition into ductus.

Male unknown

DIAGNOSIS AND TAXONOMIC POSITION. Judging by the external characters and female genital structure, the new genus belongs to the subfamily Cossinae Leach, 1815 (type genus Cossus Fabricius, 1793). This is indicated by the long ovipositor, the small cup-like ostium, the specific appearance of the adult. It is necessary to note that females only of fifteen Cossinae genera (among the 69 described valid genera of the world fauna) have bipectinate antenna: Paropta

How to cite this article: Saldaitis A., Yakovlev R.V. 2019. Rasa litanga a new genus and species of Carpenter Moth (Lepidoptera: Cossidae, Cossinae) from Sichuan Province (China) // Russian Entomol. J. Vol.28. No.2. P.183 -185. doi: 10.15298/rusentj.28.2.11 
Staudinger, 1899 (type species Cossus paradoxus HerrichSchäffer, [1851], by monotypy), Semitocossus Yakovlev, 2007 (type species Paropta johannes Staudinger, 1899, by monotypy), Brachylia Felder, 1874 (type species Brachylia terebroides Felder, 1874, by monotypy), Gumilevia Yakovlev, 2011 (type species Gumilevia zhiraph Yakovlev, 2011, by original designation), Wiltshirocossus Yakovlev, 2007 (type species Cossus aries Püngeler, 1902, by monotypy), Acossus Dyar, 1905 (type species Cossus undosus Lintner, 1878, by original designation), Chingizid Yakovlev, 2011 (type species Lamellocossus transaltaica Daniel, 1970, by original designation), Gobibatyr Yakovlev, 2004 (type species Cossus colossus Staudinger, 1887, by original designation), Coryphodema Felder, 1874 (type species Coryphodema capensis Felder, 1874, by monotypy), Brachygystia Schoorl, 1990 (type species Cossus mauretanicus Lucas, 1907, by monotypy), Eogystia Schoorl, 1990 (type species Hypopta sibirica Alpheraky, 1885, by monotypy), Isoceras Turati, 1924 (type species Isoceras kruegeri Turati, 1924, by monotypy), Stygioides Bruand, 1853 (type species Stygia colchica Herrich-Schäffer, 1851, by monotypy), Dieida Strand in Stichel, 1911 (type species Dieida persa Strand in Stichel, 1911, by monotypy), Semagystia Schoorl, 1990 (type species Endagria agilis Christoph, 1884, by original designation). The most important distinctive features of the new genus are: the specific fore wing pattern and strong basal thickening of the anterior apophyses. Currently, it is impossible to indicate exactly the allied genera.

\section{Rasa litanga Saldaitis et Yakovlev, sp.n.} Figs 1-3.

MATERIAL: holotype,, , China, W. Sichuan, near Litang, H4000 m, N 2949.136', E 100²0.576', 15.vi.2015, leg. Floriani \& Saldaitis, (in the micro tube) (coll. ASV = A. Saldaitis (Vilnius, Lithuania) later to be deposited in the WIGJ = World Insect Gallery, Joniškis, Lithuania); paratype, 9 , China, W. Szechuan, $80 \mathrm{~km}$ NW Litang, Haizy-Shan, lake, 4500-4600 m, 8.07.2018, leg. M. Markhasev (RYB).

DESCRIPTION. Wingspan $51 \mathrm{~mm}$. Antenna bipectinate. Length of crest processes (in middle third of antenna) 1,2 times bigger than rod diameter. Length of antenna equal to 0.5 of fore wing length. Tegula and patagium pale brown. Abdomen covered with orange hairs. Fore wing pale brown, with dark brown pattern: costal edge brown with poorly
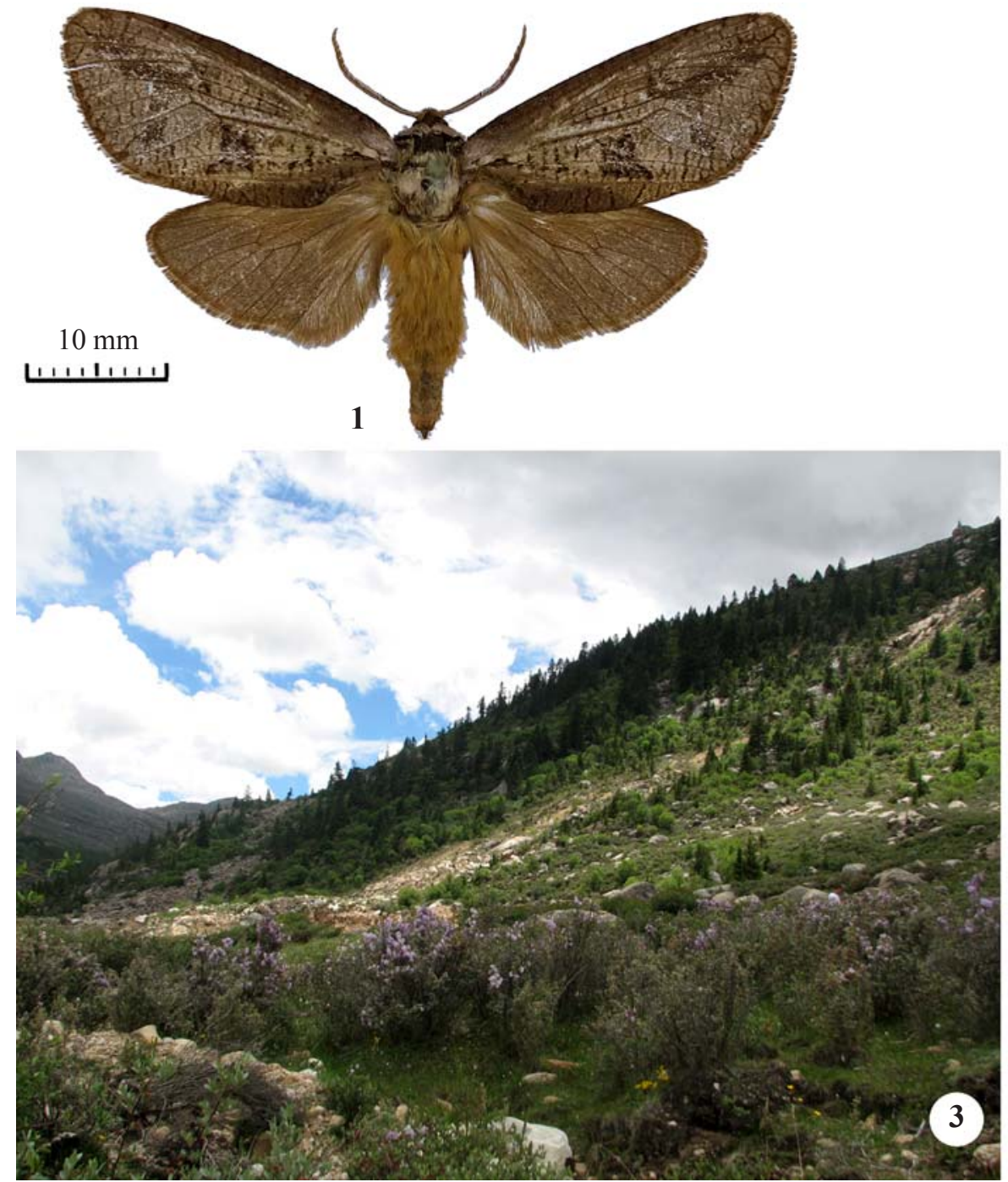

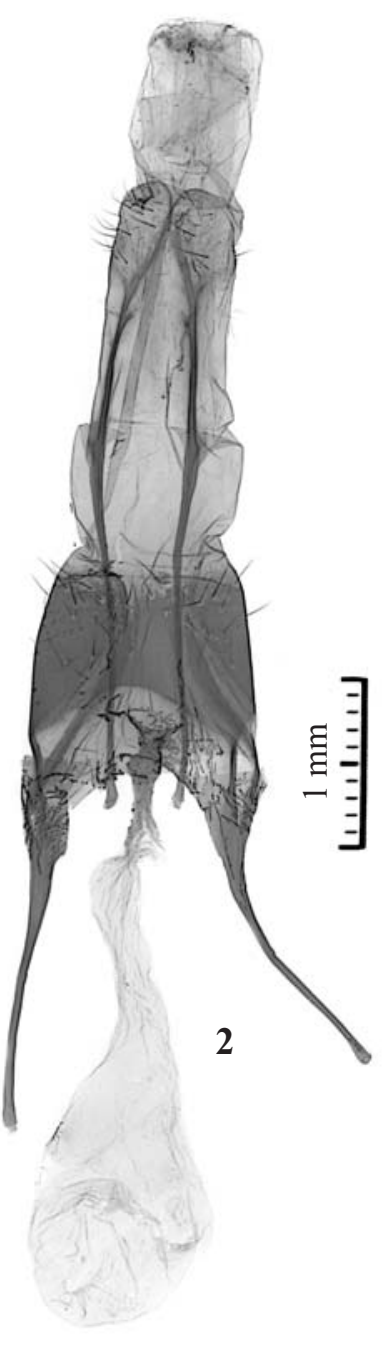

Figs 1-3. Rasa litanga, gen. et sp.n.: 1 - female, holotype (ASV/WIGJ); 2 - female genitalia; 3 - biotope (photo by A. Saldaitis). Рис. 1-3. Rasa litanga, gen. et sp.n.: 1 - самка; голотип (ASV/WIGJ); 2 - гениталии самки; 3 - биотоп (фото А. Салдаитиса). 
noticeable dark brown transverse strokes, poorly contrast dark brown undulate strokes throughout wing, blurred dark brown patches in discal area (between veins of cubital trunk), dark brown spots merging into oblique band in postdiscal area (between veins of medial trunk), fringe pale brown, unicolorous. Hind wing pale brown without pattern, fringe pale brown, unicolorous.

Female genitalia (Fig. 2) - see the genus description.

Male unknown.

BIOLOGY AND DISTRIBUTION. Single female was collected at ultraviolet light at 15 June, 2015 in a remote part of Litang County in southwestern Sichuan Province's Shaluli Shan mountain range. The new species was collected at altitudes of approximately 4000 meters in mountain mixed forests dominated by various conifer trees, bushes and rhododendron.

ETYMOLOGY. The new genus is named in honor of Rasa Saldaitienë (Vilnius, Lithuania) for her deep understanding and support of the entomological activities of the senior author, "rasa" in Lithuanian language means "morning dew"; species name is toponymical.

Acknowledgments. The authors are grateful to Anna Ustjuzhanina (Tomsk) for language improvements, to Maxim Markhasev (Moscow) for new material from China, to Thomas Witt (Munich) for providing comfortable conditions to work with his collection and library and to Alessandro Floriani (Milan, Italy) for his enthusiasm and patience during the China trips.

\section{References}

Hua B., Chou I., Fang D., Chen S. 1990. The Cossid fauna of China (Lepidoptera, Cossidae). Yangling: Tianze Eldonejo. 147 pp.

Ivinskis P., Rimsaite J., Saldaitis A., Yakovlev R. 2012. Description of two new species of Cossidae (Lepidoptera) from China // ZooKeys. Vol.192. P.35-49.

Lafontaine J.D. 2004. Noctuoidea, Noctuidae (part), Noctuinae (part Agrotini) // R. W. Hodges (ed.). The Moths of America North of Mexico. Washington: The Wedge Entomological Research Foundation. Fasc.27.1. P.13-85.

Saldaitis A., Ivinskis P. 2010. Wittocossus dellabrunai (Lepidoptera, Cossidae), a new species from China // Esperiana. Vol.15. P.383-386.

Yakovlev R.V. 2004a. New data about Carpenter-Moths (Cossidae) of China // Atalanta. Bd.35. Nos3-4. P.353-356.

Yakovlev R.V. 2004b. New taxa of Cossidae from SE Asia // Atalanta. Bd.35. Nos3-4. P.369-382.

Yakovlev R.V. 2011. Catalogue of the Family Cossidae of the Old World (Lepidoptera) // Neue Entomologische Nachrichten. Bd.66. P.1-130.

Yakovlev R.V., Saldaitis A., Kons H., Borth R. 2013. A brief review of genus Catopta Staudinger, 1899 (Lepidoptera: Cossidae) with description of a new species from China // Zootaxa. Vol.3709. No.4. P.330-340. http://dx.doi.org/10.11646/zootaxa.3709.4.2

Yakovlev R.V., Saldaitis A., Pekarsky O. 2016. A new species of Dyspessa Hübner, (Lepidoptera, Cossidae) from Western China, with catalogue of Chinese species of the genus // Zootaxa. Vol.4107. No.1. P.85-88. http://doi.org/10.11646/zootaxa.4107.1.5 